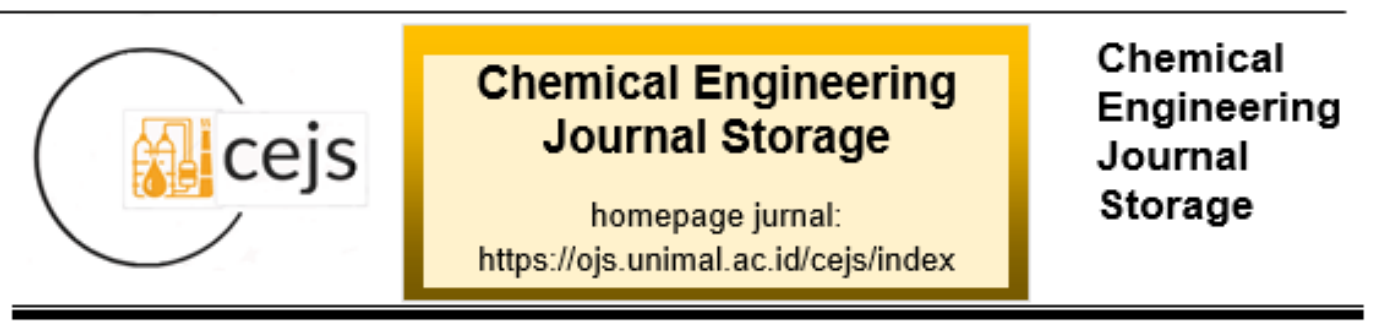

\title{
PENGARUH KECEPATAN PENGADUKAN DAN DOSIS PENAMBAHAN KOAGULAN ALAMI DARI SELULOSA KULIT BIJI BUNGA MATAHARI (Helianthus annus L) TERHADAP PENURUNAN KADAR TSS DAN TDS
}

\author{
Nurul Azizah $^{1}$, Masrulita ${ }^{1}$, Suryati $^{1}$, Meriatna ${ }^{1}$, Syamsul Bahri ${ }^{1}$. \\ ${ }^{1}$ Jurusan Teknik Kimia, Fakultas Teknik, Universitas Malikussaleh \\ Kampus Utama Cot Teungku Nie Reuleut, Muara Batu, Aceh Utara - 24355 \\ Korespondensi:HP: 081320936938, e-mail: masrulita@unimal.ac.id
}

\begin{abstract}
Abstrak
Laundry merupakan suatu proses kompleks yang melibatkan interaksi antara beberapa faktor fisik dan kimiawi. Air limbah yang dihasilkan dari proses laundry mempunyai komposisi dan kandungan yang bervariasi. Penelitian ini bertujuan untuk menganalisis pengaruh waktu pengadukan dan dosis penambahan koagulan terhadap penurunan, TDS dan TSS pada limbah laundry. Penelitian dilakukan dengan mengambil ekstrak selulosa kulit biji bunga matahari melalui proses ekstraksi menggunakan larutan asam nitrit yang selanjutnya dipanaskan di atas hot plate kemudian dicuci. Selanjutnya didelignifikasi dengan larutan $\mathrm{NaOH}$ kemudian dicuci lalu dilakukan pemutihan dengan $\mathrm{NaOCl}$ kemudian dimasukkan ke dalam oven sehingga diperoleh selulosa. Metode analisis yang digunakan pada penelitian ini menggunakan metode jar tes, selanjutnya dianalisa kadar TDS dan TSS, serta suhu dan pH. yang diperoleh pada penelitian ini menunjukkan kadar TDS dan TSS pada sampel masing-masing mencapai $450 \mathrm{mg} / \mathrm{l}$, dan $400 \mathrm{mg} / \mathrm{l}$. Selanjutnya dilakukan proses flokulasi dan koagulasi dengan metode jar tes didapatkan hasil penurunan kadar TDS dengan koagulan selulosa kuit biji bunga matahari $387 \mathrm{mg} / \mathrm{l}$ (dosis $700 \mathrm{mg} / \mathrm{l}$, $40 \mathrm{rpm}$ ). Dalam penurunan kadar TSS diperoleh $100 \mathrm{mg} / \mathrm{l}$ (dosis $700 \mathrm{mg} / \mathrm{l}, 40 \mathrm{rpm}$ ). Berdasarkan hasil yang diperoleh selulosa kulit biji bunga matahari mampu menurunkan kadar TDS dan TSS pada limbah laundry.
\end{abstract}

Kata kunci: Jar test, koagulan, laundry, pengadukan, selulosa kulit biji bunga matahari

\section{Pendahuluan}

Air merupakan komponen yang sangat penting untuk keberlangsungan hidup.

Kebutuhan air bersih akan terus meningkat seiring bertambahnya jumlah populasi 
di dunia. Kebutuhan air bersih terus meningkat tiap tahun, akan tetapi sumber air bersih terus mengalami penurunan tiap tahun. Laundry merupakan suatu proses kompleks yang melibatkan interaksi antara beberapa faktor fisik dan kimiawi. Air limbah yang dihasilkan dari proses laundry mempunyai komposisi dan kandungan yang bervariasi. Tanpa adanya proses pengolahan air yang memadai, air yang sudah tercemar dapat membebani bahkan melampaui kesanggupan alam untuk membersihkannya. Proses pengolahan air yang memadai merupakan salah satu kunci dalam memelihara kelestarian lingkungan, Pencemaran utama pada air diakibatkan oleh limbah rumah tangga, limbah industri, dan limbah pertanian (Said \& Ruliasih, 2005).

Metode koagulasi merupakan salah satu metode yang cukup banyak diaplikasikan pada pengolahan air. Proses koagulasi adalah proses pengendapan partikel yang tersuspensi dengan menggunakan bahan kimia (Hidayat, 2016) . Pada metode ini biasanya digunakan suatu koagulan sintetik. Koagulan yang umumnya dipakai adalah garam-garam aluminium seperti aluminium sulfat dan PAC (poly aluminum chloride) (Alrumman, 2016).

Penggunaan teknologi koagulan alami merupakan pilihan yang tepat, karena biaya yang reatif lebih murah. Salah satunya yaitu menggunakan selulosa dari tumbuhan. Selulosa adalah salah satu komponen kerangka yang paling penting dalam biomassa lignoselulosa yang ketersediaannya di alam tidak pernah habis danbiasanya dimanfaatkan sebagai bahan ramah lingkungan (Huber, 2012). Partikel selulosa dicirikan memiliki tingkat kekristalan yang tinggi dan mempunyai ukuran dari beberapa ratus nanometer (nm) sampai 100 mikrometer $(\mu \mathrm{m})$.

Jar tes atau uji jar merupakan metode standar yang digunakan untuk menguji proses koagulasi. Data yang didapat dengan melakukan jar test antara lain dosis optimum penambahan koagulan, lama pengendapan serta volume endapan yang terbentuk. Jar test yang dilakukan adalah untuk membandingkan kinerja koagulan yang digunakan untuk mendapatkan padatan yang tersuspensi yang terdapat pada air sungai (Tobergte \& Curtis, 2013). Metode pengujian koagulasi dan flokulasi dengan cara jartest ditetapkan dalam SNI 19-6449-2000 termasuk prosedur umum 
untuk pengolahan dalam rangka mengurangi bahan terlarut, koloid dan yang tidak mengendap dalam air dengan menggunakan zat kimia pada proses koagulasi flokulasi dan dilanjutkan dengan proses pengendapan (Badan Standardisasi Nasional, 2000).

\section{Bahan dan Metode}

Bahan yang diperlukan dalam penelitian ini antara lain adalah kulit biji bunga matahari, limbah laundry, $\mathrm{HNO}_{3}, \mathrm{NaNO}_{2}, \mathrm{NaOH}, \mathrm{Na}_{2} \mathrm{SO}_{2}, \mathrm{NaOCl}, \mathrm{H}_{2} \mathrm{O}_{2}$ dan aquadest. Adapun peralatan yang digunakan pada penelitian ini antara lain adalah hot plate, blender, desikator, beaker glass, kertas saring, seperangkat alat jar tes, oven, kertas saring, termometer, ph meter, dan TDS meter.

Penelitian ini terdiri dari empat tahap yaitu tahapan preparasi kulit biji bunga matahari, tahapan isolasi selulosa, pengujian standar dengan jar tes dan pengujian TDS serta TSS.

Tahap pertama yaitu persiapan kulit biji bunga matahari sebagai koagulan, kemudian pengujian dengan jar test dan pengujian TDS serta TSS. Tahap persiapan koagulan kulit biji bunga matahari dengan cara dihaluskan menjadi ukuran yang lebih kecil berbentuk serbuk, kemudia uji dengan jar tes.

Tahap kedua isolasi selulosa dengan mempersiapkan kulit biji bunga matahari yang telah dihaluskan, kemudian ditambahkan $\mathrm{HNO}_{3}$ dan $\mathrm{NaNO}_{2}$ lalu dipanaskan di atas hot plate sehingga diperoleh filtrat. Selanjutnya proses delignifkasi dengan menggunakan basa kuat berupa $\mathrm{NaOH}$ dan ditambahkan $\mathrm{Na}_{2} \mathrm{SO}_{3}$. Proses ini merupakan proses penghilangan lignin pada kulit biji bunga matahari, karena dengan adanya lignin ini akan membuat sampel yng diuji mengalami penambahan warna yang tidak diinginkan. Selanjutnya dilakukan tahap pemutihan dengan larutan $\mathrm{NaOCl}$ pada temperature mendidih, dan dilanjutkan dengan pemutihan kembali dengan $\mathrm{H}_{2} \mathrm{O}_{2}$ dengan memastikan tidak ada kandungan lignin yang tersisa.

Tahap ketiga pengujian dengan menggunakan jar tes. Metode jar tes pada penelitian ini memvariasikan koagulan menjadi empat variasi, yaitu $200 \mathrm{mg} / \mathrm{l}, 300$ $\mathrm{mg} / \mathrm{l}, 500 \mathrm{mg} / \mathrm{l}$ dan $700 \mathrm{mg} / \mathrm{l}$ dengan dosis sampel air laundry $500 \mathrm{ml}$. Kecepatan 
pengadukan divariasikan menjadi $20 \mathrm{rpm}, 40 \mathrm{rpm}, 80 \mathrm{rpm}$ dan $100 \mathrm{rpm}$, sehingga diperoleh pengulangan sebanyak 16 kali run. Setelah dilakukan uji jar tes selanjutnya diamati dan diamkan dalam waktu beberapa menit, lalu di analisa kadar TDS, TSS, $\mathrm{pH}$, dan suhu.

Tahap keempat analisa TDS dan TSS dilakukan untuk mengetahui padatan yang terlarut dalam suatu larutan dan padatan yang tidak terlarut dalam larutan. Analisa TDS dilakukan menggunakan TDS meter, sedangkan analisa TSS menggunakan metode gravimetri.

\section{Hasil dan Diskusi}

\subsection{Hasil Analisa Kadar TDS pada Sampel laundry dengan Menggunakan}

\section{Selulosa Kulit Biji Bunga Matahari (Helianthus Annus L.)}

Pengujian terhadap kadar TDS dilakukan untuk mengetahui penurunan kadar TDS (Total Dissolved Solid). Data-data yang diperoleh dari percobaan adalah data yang diperoleh setelah dilakukannya uji dengan jar selanjutnya diukur kadar TDS dengan menggunakan TDS meter. Hasil analisa kadar TDS pada sampel laundry dengan menggunakan selulosa kulit biji bunga matahari dapat dilihat pada Tabel 3.1 .

Tabel 3.1 Hasil Analisa Kadar TDS pada Sampel laundry dengan Menggunakan Selulosa Kulit Biji Bunga Matahari (Helianthus Annus L.)

\begin{tabular}{|c|c|c|c|c|}
\hline Run & Konsentrasi & Temperatur $\left({ }^{0} \mathrm{C}\right)$ & pH & TDS (mg/L) \\
\hline 0 & Blanko & 28 & 8.8 & 450 \\
\hline 1 & $200 \mathrm{mg} / 20 \mathrm{rpm}$ & \multirow{4}{*}{28} & 8 & 440 \\
\hline 2 & $200 \mathrm{mg} / 40 \mathrm{rpm}$ & & 7.8 & 390 \\
\hline 3 & $200 \mathrm{mg} / 80 \mathrm{rpm}$ & & 8 & 439 \\
\hline 4 & $200 \mathrm{mg} / 100 \mathrm{rpm}$ & & 8 & 435 \\
\hline & & \multirow{5}{*}{28} & & \\
\hline 5 & $300 \mathrm{mg} / 20 \mathrm{rpm}$ & & 8 & 435 \\
\hline 6 & $300 \mathrm{mg} / 40 \mathrm{rpm}$ & & 7.8 & 395 \\
\hline 7 & $300 \mathrm{mg} / 80 \mathrm{rpm}$ & & 8 & 448 \\
\hline 8 & $300 \mathrm{mg} / 100 \mathrm{rpm}$ & & 7.8 & 450 \\
\hline 9 & $500 \mathrm{mg} / 20 \mathrm{rpm}$ & \multirow{2}{*}{28} & 8 & 420 \\
\hline 10 & $500 \mathrm{mg} / 40 \mathrm{rpm}$ & & 8 & 392 \\
\hline
\end{tabular}




\begin{tabular}{|c|c|c|c|c|}
\hline 11 & $500 \mathrm{mg} / 80 \mathrm{rpm}$ & & 7.8 & 450 \\
\hline 12 & $500 \mathrm{mg} / 100 \mathrm{rpm}$ & & 7.8 & 447 \\
\hline 13 & $700 \mathrm{mg} / 20 \mathrm{rpm}$ & \multirow{4}{*}{28} & 8 & 433 \\
\hline 14 & $700 \mathrm{mg} / 40 \mathrm{rpm}$ & & 8 & 387 \\
\hline 15 & $700 \mathrm{mg} / 80 \mathrm{rpm}$ & & 7.8 & 451 \\
\hline 16 & $700 \mathrm{mg} / 100 \mathrm{rpm}$ & & 7.8 & 447 \\
\hline
\end{tabular}

Dapat dilihat pada Tabel 3.1 koagulan dengan selulosa dari kulit biji bunga matahari mampu menurunkan kadar TDS pada sampel air laundry, sedangkan koagulan dengan kulit biji bunga matahari dapat dilihat pada Tabel 3.2.

Tabel 3.2 Hasil Analisa Kadar TDS pada Sampel laundry dengan Menggunakan Kulit Biji Bunga Matahari (Helianthus Annus L.)

\begin{tabular}{|c|c|c|c|c|}
\hline Run & Konsentrasi & Temperatur $\left({ }^{0} \mathrm{C}\right)$ & pH & TDS (mg/L) \\
\hline 0 & Blangko & 28 & 8 & 325 \\
\hline 1 & $200 \mathrm{mg} / 20 \mathrm{rpm}$ & \multirow{4}{*}{28} & \multirow{4}{*}{8} & 280 \\
\hline 2 & $200 \mathrm{mg} / 40 \mathrm{rpm}$ & & & 251 \\
\hline 3 & $200 \mathrm{mg} / 80 \mathrm{rpm}$ & & & 262 \\
\hline 4 & $200 \mathrm{mg} / 100 \mathrm{rpm}$ & & & 263 \\
\hline 5 & $300 \mathrm{mg} / 20 \mathrm{rpm}$ & \multirow{4}{*}{28} & \multirow{4}{*}{8} & 275 \\
\hline 6 & $300 \mathrm{mg} / 40 \mathrm{rpm}$ & & & 255 \\
\hline 7 & $300 \mathrm{mg} / 80 \mathrm{rpm}$ & & & 258 \\
\hline 8 & $300 \mathrm{mg} / 100 \mathrm{rpm}$ & & & 263 \\
\hline 9 & $500 \mathrm{mg} / 20 \mathrm{rpm}$ & \multirow{4}{*}{28} & \multirow{4}{*}{8} & 273 \\
\hline 10 & $500 \mathrm{mg} / 40 \mathrm{rpm}$ & & & 254 \\
\hline 11 & $500 \mathrm{mg} / 80 \mathrm{rpm}$ & & & 267 \\
\hline 12 & $500 \mathrm{mg} / 100 \mathrm{rpm}$ & & & 265 \\
\hline 13 & $700 \mathrm{mg} / 20 \mathrm{rpm}$ & \multirow{4}{*}{28} & \multirow{4}{*}{8} & 272 \\
\hline 14 & $700 \mathrm{mg} / 40 \mathrm{rpm}$ & & & 259 \\
\hline 15 & $700 \mathrm{mg} / 80 \mathrm{rpm}$ & & & 264 \\
\hline 16 & $700 \mathrm{mg} / 100 \mathrm{rpm}$ & & & 262 \\
\hline
\end{tabular}




\subsection{Hubungan Kecepatan Pengadukan Terhadap Kadar TDS (mg/L) Pad}

\section{Koagulan Selulosa Kulit Biji Bunga Matahari (Helianthus annus L)}

Selulosa memiliki tingkat kekristalan yang tinggi dan mempunyai ukuran dari beberapa ratus nanometer $(\mathrm{nm})$ sampai 100 mikrometer $(\mu \mathrm{m})$. Sehingga dapat dijadikan sebagai koagulan alami pada proses pengolahan air limbah laundry (Oliveira, 2016). Adapun penurunan kadar TDS pada sampel limbah laundry dengan selulosa kulit biji bunga matahari dapat dilihat pada Gambar 4.3.

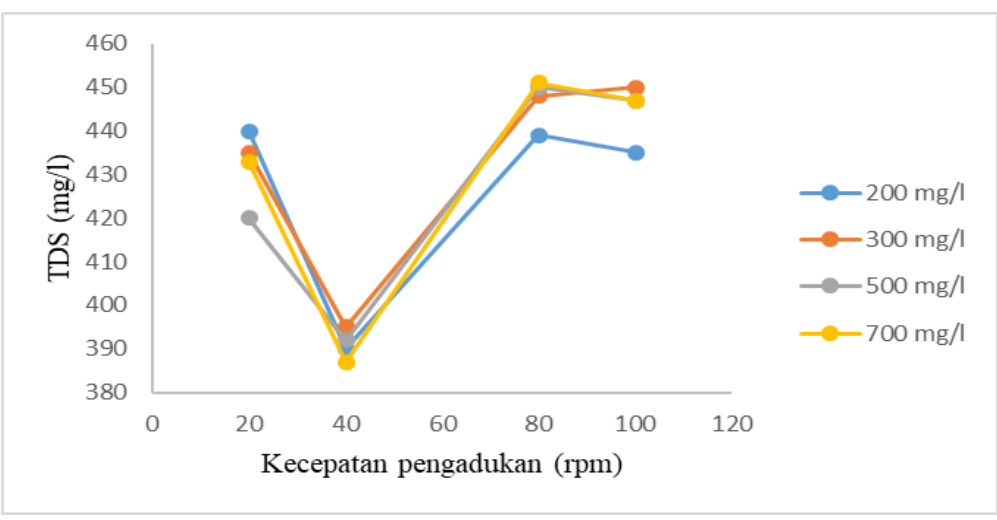

Gambar 3.1 Hubungan kecepatan pengadukan terhadap kadar TDS (mg/l) pada koagulan selulosa kulit biji bunga matahari

Dapat dilihat pada gambar 4.2 secara umum dapat dilihat bahwa pada kecepatan pengadukan $40 \mathrm{rpm}$ mengalami penurunan kadar TDS. Hal ini disebabkan karena adanya kandungan selulosa yang mampu mengikat kandungan tds pada sampel sehingga terbentuk flok disertai juga dengan adanya pengadukan yang tidak terlalu cepat dan juga terlalu lambat. Sedangkan pada kecepatan pengadukan $80 \mathrm{rpm}$, dan $100 \mathrm{rpm}$ mengalami kenaikan kadar TDS. Hal ini disebakan karena pengadukan yang terlalu cepat dapat mengakibatkan flok yang sudah terbentuk dapat pecah (Setiawan, 2001). Hasil yang diperoleh mampu menurunkan menjadi $387 \mathrm{mg} / \mathrm{L}$, dimana kadar maksimum yang diperbolehkan yaitu 500 mg/L (Kementrian Lingkungan Hidup, 1995). Diperoleh kondisi optimum pada kecepatan pengadukan $40 \mathrm{rpm}$ dengan dosis penambahan selulosa kulit biji bunga matahari $700 \mathrm{mg}$. Pada kondisi tersebut dapat menurunkan kadar TDS menjadi $387 \mathrm{mg} / \mathrm{L}$, hal ini disebabkan karena adanya proses pencampuran koagulan kedalam air baku sehingga menyebabkan partikel padatan yang 
mempunyai padatan ringan dan ukurannya kecil menjadi lebih berat dan ukurannya besar (flok) yang mudah mengendap. Berdasarkan Gambar 4.2 diperoleh kadar TDS tertinggi pada kecepatan pengadukan $100 \mathrm{rpm}$ dan dosis koagulan 300 mg, mengalami kenaikan kadar TDS, hal ini disebabkan karena kecepatan pengadukan yang terlalu tinggi dapat memecah flok yang sudah terbentuk sehingga kadar TDS semakin meningkat (Setiawan, 2001).

Sedangkan hubungan kecepatan pengadukan terhadap penurunan kadar TDS dengan menggunakan koagulan kulit biji bunga matahari dapat dilihat pada Gambar 3.2.

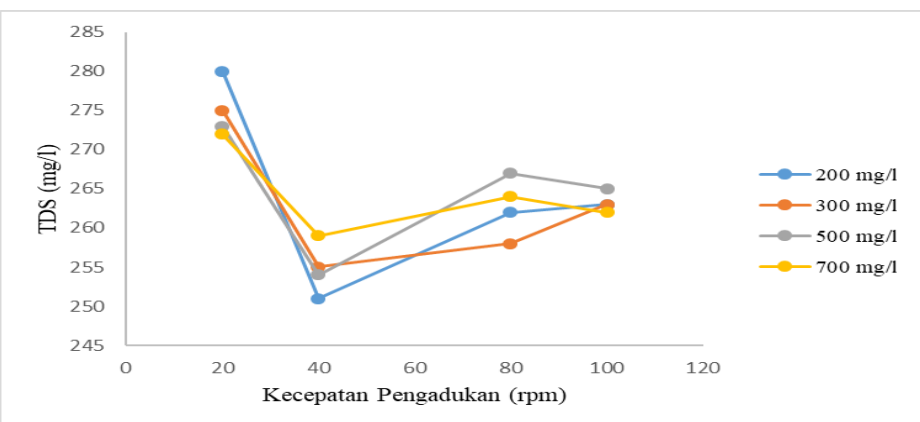

Gambar 3.2 Hubungan kecepatan pengadukan terhadap kadar TDS (mg/l) pada koagulan kulit biji bunga matahari

Dapat dilihat pada Gambar 3.2 secara umum dapat dilihat bahwa dengan menggunakan metode jar tes yang memanfaatkan kulit biji bunga matahari sebagai koagulan dapat menurunkan kadar TDS. Akan tetapi pada pengadukan 80 rpm dan 100 rpm mengalami kenaikan kadar TDS, hal ini disebabkan karena adanya pengadukan yang teralu cepat, sehingga mengakibatkan flok yang terbentuk menjadi pecah, sehingga kadar TDS pada sampel menjadi meningkat (Budiman, 2017).

\subsection{Analisa Kadar TSS pada Sampel laundry dengan Menggunakan Selulosa Kulit Biji Bunga Matahari (Helianthus Annus L.)}

Proses pengolahan air limbah merupakan salah satu langkah penting untuk memperoleh air bersih akan tetapi terdapat beberapa parameter yang perlu diperhatikan sehingga diperoleh air yang dapat digunakan kembali atau dapat menjadikan limbah tersebut layak untuk dibuang ke lingkungan sehingga tidak 
mencemari lingkungan. Hasil analisa kadar TSS pada sampel laundry dengan menggunakan selulosa kulit biji bunga matahari dapat dilihat pada Tabel 3.3.

Tabel 3.3 Hasil Analisa Kadar TSS pada Sampel laundry dengan Menggunakan Selulosa Kulit Biji Bunga Matahari (Helianthus Annus L.)

\begin{tabular}{|c|c|c|c|c|}
\hline Run & Konsentrasi & Temperatur $\left({ }^{0} \mathrm{C}\right)$ & pH & TSS (mg/L) \\
\hline 0 & Blangko & 28 & 8.8 & 400 \\
\hline 1 & $200 \mathrm{mg} / 20 \mathrm{rpm}$ & \multirow{4}{*}{28} & 8 & 300 \\
\hline 2 & $200 \mathrm{mg} / 40 \mathrm{rpm}$ & & 7.8 & 100 \\
\hline 3 & $200 \mathrm{mg} / 80 \mathrm{rpm}$ & & 8 & 200 \\
\hline 4 & $200 \mathrm{mg} / 100 \mathrm{rpm}$ & & 8 & 200 \\
\hline 5 & $300 \mathrm{mg} / 20 \mathrm{rpm}$ & \multirow{4}{*}{28} & 8 & 300 \\
\hline 6 & $300 \mathrm{mg} / 40 \mathrm{rpm}$ & & 7.8 & 200 \\
\hline 7 & $300 \mathrm{mg} / 80 \mathrm{rpm}$ & & 8 & 200 \\
\hline 8 & $300 \mathrm{mg} / 100 \mathrm{rpm}$ & & 7.8 & 300 \\
\hline 9 & $500 \mathrm{mg} / 20 \mathrm{rpm}$ & 28 & 8 & 200 \\
\hline 10 & $500 \mathrm{mg} / 40 \mathrm{rpm}$ & \multirow{3}{*}{28} & 8 & 100 \\
\hline 11 & $500 \mathrm{mg} / 80 \mathrm{rpm}$ & & 7.8 & 200 \\
\hline 12 & $500 \mathrm{mg} / 100 \mathrm{rpm}$ & & 7.8 & 300 \\
\hline 13 & $700 \mathrm{mg} / 20 \mathrm{rpm}$ & \multirow{4}{*}{28} & 8 & 300 \\
\hline 14 & $700 \mathrm{mg} / 40 \mathrm{rpm}$ & & 8 & 100 \\
\hline 15 & $700 \mathrm{mg} / 80 \mathrm{rpm}$ & & 7.8 & 200 \\
\hline 16 & $700 \mathrm{mg} / 100 \mathrm{rpm}$ & & 7.8 & 300 \\
\hline
\end{tabular}

TSS (Total Suspended Solids) merupakan padatan yang terdapat pada larutan namun tidak terlarut, terdiri dari partikel - partikel yang berat dan ukurannya lebih kecil dibandingkan dengan sedimen. Pengujian terhadap kadar TSS dilakukan untuk mengetahui penurunan kadar TSS (Total Suspended Solid). Data-data yang diperoleh dari percobaan adalah data yang diperoleh setelah 
dilakukannya uji dengan jar selanjutnya diukur kadar TSS dengan menggunakan metode perhitungan berdasarkan SNI06-6989.3-2004 (Badan Standardisasi Nasional, 2004) .

$\mathrm{TSS}=\frac{\text { (massa kertas saring akhir-massa kertas saring awal) } \times 1000}{\mathrm{~V}(\mathrm{~L})}$

Sedangkan hasil analisa kadar TSS dengan menggunakan kulit biji bunga matahari dapat dilihat pada tabel 3.4.

Tabel 3.4 Hasil Analisa Kadar TSS pada Sampel laundry dengan Menggunakan Kulit Biji Bunga Matahari (Helianthus Annus L.)

\begin{tabular}{|c|c|c|c|c|}
\hline Run & Konsentrasi & Temperatur $\left({ }^{0} \mathrm{C}\right)$ & $\mathbf{p H}$ & TSS (mg/L) \\
\hline 0 & Blangko & 28 & 8.8 & 400 \\
\hline 1 & $200 \mathrm{mg} / 20 \mathrm{rpm}$ & \multirow{4}{*}{28} & 8 & 300 \\
\hline 2 & $200 \mathrm{mg} / 40 \mathrm{rpm}$ & & 7.8 & 100 \\
\hline 3 & $200 \mathrm{mg} / 80 \mathrm{rpm}$ & & 8 & 200 \\
\hline 4 & $200 \mathrm{mg} / 100 \mathrm{rpm}$ & & 8 & 200 \\
\hline 5 & $300 \mathrm{mg} / 20 \mathrm{rpm}$ & \multirow{4}{*}{28} & 8 & 300 \\
\hline 6 & $300 \mathrm{mg} / 40 \mathrm{rpm}$ & & 7.8 & 200 \\
\hline 7 & $300 \mathrm{mg} / 80 \mathrm{rpm}$ & & 8 & 200 \\
\hline 8 & $300 \mathrm{mg} / 100 \mathrm{rpm}$ & & 7.8 & 300 \\
\hline 9 & $500 \mathrm{mg} / 20 \mathrm{rpm}$ & 28 & 8 & 200 \\
\hline 10 & $500 \mathrm{mg} / 40 \mathrm{rpm}$ & 28 & 8 & 100 \\
\hline 11 & $500 \mathrm{mg} / 80 \mathrm{rpm}$ & \multirow{6}{*}{28} & 7.8 & 200 \\
\hline 12 & $500 \mathrm{mg} / 100 \mathrm{rpm}$ & & 7.8 & 300 \\
\hline 13 & $700 \mathrm{mg} / 20 \mathrm{rpm}$ & & 8 & 300 \\
\hline 14 & $700 \mathrm{mg} / 40 \mathrm{rpm}$ & & 8 & 100 \\
\hline 15 & $700 \mathrm{mg} / 80 \mathrm{rpm}$ & & 7.8 & 200 \\
\hline 16 & $700 \mathrm{mg} / 100 \mathrm{rpm}$ & & 7.8 & 300 \\
\hline
\end{tabular}


Berdasarkan hasil analisa kadar TSS dengan kulit biji bunga matahari tidak menurunkan kadar TSS terhadap blangko, akan tetapi menambah kadar TSS pada sampel.

\subsection{Hubungan Kecepatan Pengadukan Terhadap Kadar TSS (Mg/L) Pada}

Koagulan Selolasa Kulit Biji Bunga Matahari (Helianthus annus L)

Adapun Hubungan kecepatan pengadukan terhadap kadar TSS (mg/L) pada koagulan selolasa kulit biji bunga matahari dapat dilihat pada Gambar 3.4.

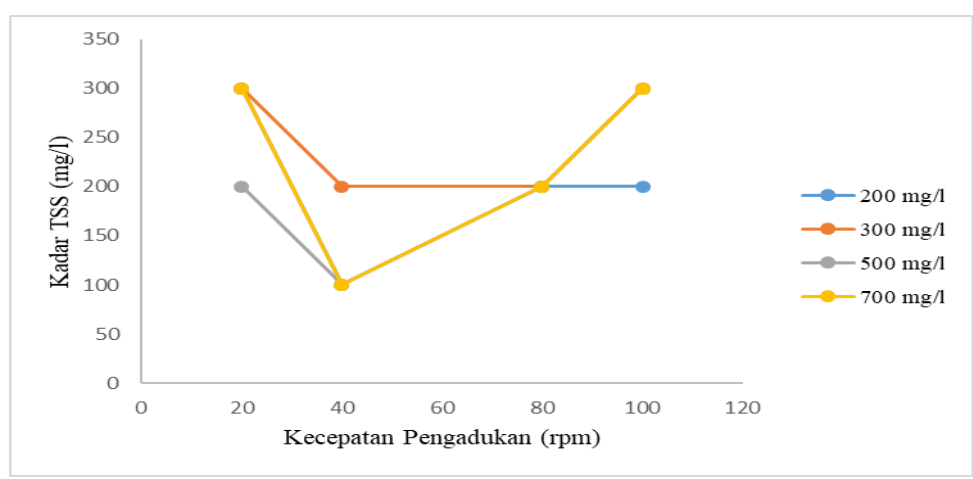

Gambar 3.4 Hubungan kecepatan pengadukan terhadap kadar TSS (mg/L) pada koagulan selolasa kulit biji bunga matahari

Berdasarkan Gambar 4.4 yang diperoleh menggunakan metode jar tes yang memanfaatkan selulosa kulit biji bunga matahari sebagai koagulan yang dapat menurunkan kadar TSS dapat dilihat pada Gambar 4.4. Diperoleh kondisi optimum pada kecepatan pengadukan $40 \mathrm{rpm}$. Pada kondisi tersebut dapat menurunkan kadar TSS dimana kadar awal atau blanko sebesar 400 mg/L menjadi $100 \mathrm{mg} / \mathrm{L}$. Dapat dilihat pada gambar 4.4. Pada kecepatan pengadukan $100 \mathrm{rpm}$ mengalami peningkatan kadar TSS. Hal ini disebabkan karena terlalu cepat mengakibatkan flok-flok yang sudah terbentuk pecah kembali, sehingga hal ini meningkatkan nilai kadar TSS pada sampel (Susanto,2008).

Data hasil penelitian menggunakan metode jar tes yang memanfaatkan koagulan dari kulit biji bunga matahari juga dianalisa penurunan temperature pada sampel. Didapatkan hasil yang menunjukkan tidak ada penurunan suhu sampel, akan tetapi suhu yang diperoleh masih di bawah batas maksimum yang diperbolehkan yaitu $38^{\circ} \mathrm{C}$. Analisa penurunan $\mathrm{pH}$ menggunakan koagulan kulit 
biji bunga matahari tidak menunjukkan adanya penurunan $\mathrm{pH}$, akan tetapi pada koagulan selulosa kulit biji bunga matahari mengalami penurunan $\mathrm{pH}$ yaitu menjadi 7.8, dimana data ini masih dibawah kadar maksimum yang diperboehkan (Kementrian Lingkungan Hidup, 1995).

Sedangkan hubungan kecepatan pengadukan terhadap penurunan kadar TDS pada sampel menggunakan koagulan kulit biji bunga matahari dapat dilihat pada Gambar 3.4.

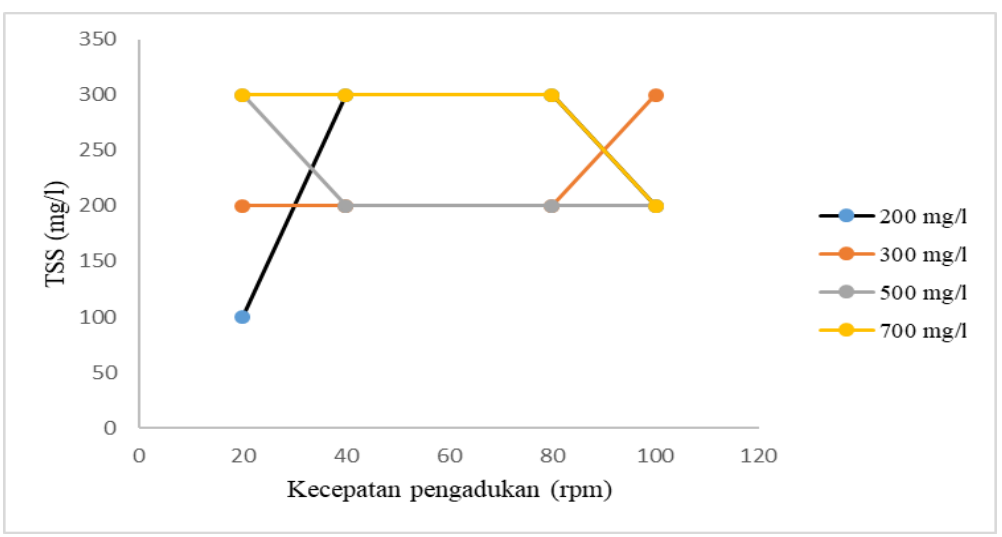

Gambar 3.4 Hubungan kecepatan pengadukan terhadap kadar TSS (mg/L) pada koagulan kulit biji bunga matahari

Dapat dilihat pada Gambar 4.4 yang diperoleh menggunakan metode jar tes yang memanfaatkan kulit biji bunga matahari sebagai koagulan yang dapat bahwa pada metode jar tes dengan menggunakan koagulan kulit biji bunga matahari dapat meningkatkan kadar TSS dimana kadar TSS terhadap sampel blangko. Hal menyebabkan kadar TSS meningkat karena koagulan yang digunakan masih berbentuk padatan kulit biji bunga matahari yang masih banyak mengandung senyawa lain yang menyebabkan kadar TSS bertambah. Kadar TSS tertinggi diperoleh pada pengadukan $100 \mathrm{rpm}$ yaitu sebesar $300 \mathrm{mg} / \mathrm{L}$. Dan juga karena pengadukan yang terlalu cepat mengakibatkan flok-flok yang sudah terbentuk pecah kembali, sehingga hal ini meningkatkan nilai kadar TSS pada sampel (Budiman et al., 2017). Sehingga kulit biji bunga matahari tidak bisa digunakan sebagai koagulan untuk menurunkan kadar TSS pada sampel air laundry. 


\section{Simpulan dan Saran}

Berdasarkan hasil penelitian yang telah diperoleh dapat disimpulkan sebagai berikut.

1. Koagulan dengan selulosa kulit biji bunga matahari menurunkan kadar TDS dan TSS pada kondisi pengadukan $40 \mathrm{rpm}$.

2. Koagulan dengan selulosa kulit biji bunga matahari menurunkan kadar TDS dan TSS pada dosis koagulan $700 \mathrm{mg}$.

3. Koagulan kulit biji bunga matahari meningkatkan kadar TSS pada sampel.

Penelitian ini dapat dilanjutkan dengan perlu adanya dilakukan analisa menggunakan metode lain untuk menurunkan parameter nilai COD dan BOD.

\section{Daftar Pustaka}

Alrumman, S. A., El-kott, A. F., \& Keshk, S. M. A. S. (2016). Water Pollution : Source and Treatment Water Pollution : Source \& Treatment. Am J Environ Eng, 6(June), 88-98. https://doi.org/10.5923/j.ajee.20160603.02

Badan Standardisasi Nasional. (2000). Metode Pengujian Koagulasi-Flokulasi dengan Cara Jar (pp. 1-11).

Badan Standardisasi Nasional. (2004). Air dan air limbah - Bagian 3: Cara uji padatan tersuspensi total (Total Suspended Solid, TSS) secara gravimetri. Sni 06-6989.3-2004, 10.

Budiman, A., Wahyudi, C., Irawati, W., \& Hindarso, H. (2017). Kinerja Koagulan Poly Aluminium Chloride (PAC) Dalam Penjernihan Air Sungai Kalimas Surabaya Menjadi Air Bersih. Widya Teknik, 7(1), 25-34. http://journal.wima.ac.id/index.php/teknik/article/view/1258

Darmasetiawan. (2001). Teori dan Perencanaan Instalasi Pengolahan Air.Bandung: Yayasan Suryono.

Hidayat, D., Rinawati, Suprianto, R., \& Sari Dewi, P. (2016). PENENTUAN KANDUNGAN ZAT PADAT (TOTAL DISSOLVE SOLID DAN TOTAL SUSPENDED SOLID)DI PERAIRAN TELUK LAMPUNG | wati | Analit: Analytical and Environmental Chemistry. Analytical and Environmental Chemistry, 1(1), 36-46. http://jurnal.fmipa.unila.ac.id/analit/article/view/1236/979

Huber, T., Müssig, J., Curnow, O., Pang, S., Bickerton, S., \& Staiger, M. P. (2012). A critical review of all-cellulose composites. Journal of Materials Science, 47(3), 1171-1186. https://doi.org/10.1007/s10853-011-5774-3

Kementrian Lingkungan Hidup. (1995). Keputusan Menteri Negara Lingkungan 
Hidup Nomor : KEP-51/MENLH/10/1995. Kementerian Lingkungan Hidup, 49. https://toolsfortransformation.net/wp-content/uploads/2017/05/51-tahun1995-Baku-mutu-limbah-cair-industri.pdf

Said, N. I., \& Ruliasih. (2005). Tinjauan Aspek Teknis Pemilihan Media Biofilter Untuk Pengolahan Air Limbah. Juurnal Agronomi Indonesia, 1(3).

Tobergte, D. R., \& Curtis, S. (2013). Analisis Penggunaan Koagulan Poly Aluminium Chloride (Pac) Dan Kitosan Pada Proses Penjernihan Air Di Pdam Tirta Pakuan Bogor. Journal of Chemical Information and Modeling, 53(9), 1689-1699. 